\title{
Basel III and Central Banks With Multiple Objectives: Convergences Between Targets*
}

\author{
Marcelo Zeuli \\ Banco Central do Brasil, Rio de Janeiro, Brazil \\ IAG/PUC, Rio de Janeiro, Brazil
}

\begin{abstract}
This text evaluates the convergence among the main targets of a Central Bank, like the Brazilian Central Bank, with that deals with objectives such as inflation targeting, bank regulation, and financial inclusion, when it operates subject to the Bank for International Settlements (BIS) recommendations gathered in the recent Basel III agreement. A Brazilian conjuncture analysis starts with the economic stabilization plan known as Plano Real (July, 1994) and takes account that, from 2007 onwards, the world economy is going through troubled times unchained by the international financial crisis that motivated the recent Basel Agreement (Basel III). There are two lines of analysis: macroeconomic and marketing. From the macroeconomic approach, there are plenty models to predict money supply and monetary aggregates. From a marketing perspective, it can be inferred that technologies potentially innovatives may alter the current scenario. The financial time series chosen are: daily money supply, banking reserves, and annual inflation (monthly announced). The first statistical and empirical evidences from the period (July, 1994 to December, 2011) show that the management of banking reserves does not interfere with the continuous growth of the monetary base plus demand deposits (M1) and cash in circulation, which possibly indicates an increasing financial inclusion. Moreover, there is no evidence that it creates inflationary pressures. The future works may require competencies pertinent to prospective finance and consumer behavior (marketing).
\end{abstract}

Keywords: Basel III, finance inclusion, inflation targeting, volatility

\section{Introduction}

The main question of this text is to evaluate if a Central Bank keeps up with the commitment of fulfilling three objectives simultaneously: inflation targeting, bank supervising (under the Basel III agreement), and financial inclusion. This question remotely points to Timbergen (1952) - to reach policy objectives a government should count on at least the same amount of independent policy instruments. A similar thought is found in Hirschman and Serra (2013): It is impossible to do everything at the same time and in a balanced way, setting up prerequisites as simultaneous.

The Brazilian conjuncture analysis has the Economic Plan named "Plano Real" (July, 1994) as a starting point. From 2007 onwards the world economy faces troubled times unchained by the international financial

\footnotetext{
* IAG/PUC and Banco Central do Brasil (Brazilian Central Bank). The views expressed in the paper are those of the author and do not necessarily reflect those of the Banco Central do Brasil.

Marcelo Zeuli, Analyst at Banco Central do Brasil; Ph.D. candidate at IAG, PUC/RJ.

Correspondence concerning this article should be addressed to Marcelo Zeuli, Rua Marquês de São Vicente, 225-Gávea-Rio de Janeiro, Brazil. E-mail: marcelo.zeuli@bcb.gov.br; m_zeuli@yahoo.com.
} 
crisis that motivated the new Basel Agreement-Basel III. Together with finance supervising, the Brazilian Central Bank has inflation targeting as the flagship of the monetary policy and also financial inclusion as the main objective

A key issue is to understand the transmission mechanisms of monetary policy, as well as investigate whether the Central Bank's macroeconomic performance favors financial inclusion or if it, conversely, causes destructive interference. Concerning to the interaction between Basel III and inflation targeting, Agénor and Pereira (2011) is a starting reference for questioning the interaction between two objectives (bank supervising and inflation targeting). In a next stage of this research, an alternative metric for the evaluation of the financial inclusion evolution will be searched.

\section{Stylized Facts}

According to AFI (2011), measuring the financial inclusion by the supply side is direct, whereas it is very difficult to evaluate the demand side, despite the increase of checking accounts. Figure B1 (see Appendix) shows that, since 2002, all cities in Brazil have bank stations (supply side). An increase in the savings rate would indicate financial inclusion. However, from Plano Real onwards, the beginning savings balance, if applied to the SELIC basic rate (main short term interest rate in Brazil), would have increased 27 times between July 4, 1994 and December 5, 2011, when, in fact, it went up 12 times. The relationship savings/M1 (monetary base + demand deposits) decreased until the beginning of the 2008 international financial crisis (see Appendix). Therefore, the financial inclusion is better observed taking into account that: Money Supply (MS) increases continuously and its participation in GDP also increase (see Figure 1 and Figure A2 in Appendix).

On the other hand, the percentage of the population with no access to electronic means of payment still is $28 \%$, a quite considerable percentage. Out of those, $10 \%$ have checking accounts and $16 \%$ savings accounts. From storeowners' perspectives, according to research done by the Brazilian Association of Credit Card \& Services Companies (ABECS) (2011), money is responsible for one third of the billings of the commerce.

The interest rate for credit cards is freely established by companies. In October 2011, the interest rate average was $10.69 \%$ per month - the equivalent to $238.30 \%$ per year, lower only to that of June 2000 (10.7\%), according to the National Association of Executives in Finance, Administration and Accounting (ANEFAC).

The economic stability after Plano Real was favorable to GDP growth and economic development. The MS and M1 increase can be taken as an indication of financial inclusion growth. An increase in the use and accumulation of traditional financial assets could be not expected considering the high interest rates and the need for cash in trading (see Figure A1 in the Appendix).

In the next sections, there is a quick literature review focusing on macroeconomics and marketing, a quick description of data and methodology, the first tests that evaluate correlations among the main series in order to find empirical evidences and the first conclusions. Some additional information is available in the Appendix, and helps to stylize the facts and complement the first evidences of the so-called high level of informality of the Brazilian economy.

\section{Literature Review}

Williamson (2000) shows that there is a time frame for contracts and a time frame do day-to-day negotiation, in the four levels of social analysis (see Figure C2 in Appendix). This statement may explain that an agreement such as the Basel III (level 3) could be time frame inconsistent with daily economic agent's 
activities, such as resource allocation and employment (level 4). Consequently, the BIS will constantly review its agreements, as seen from the BIS (2011) document:

The Committee is introducing these changes in a manner that minimizes the disruption to capital instruments that are currently outstanding. It also continues to review the role that contingent capital should play in the regulatory capital framework. (p. 11)

The Committee will put in place rigorous reporting processes to monitor the ratios during the transition period and will continue to review the implications of these standards for financial markets, credit extension and economic growth, addressing unintended consequences as necessary. (p. 18)

Macroeconomic approach: In this working paper there are two macroeconomic approaches: Minsky's (2008) financial instability hypothesis and the theory of demand for money.

\section{The Financial Instability Hypothesis}

Minsky's theories are reminded every time there is a new global financial crisis. His approach relates the economic theory to political, economic, cultural, and institutional environments. The need for financial regulations is explicit in Minsky (2008), as a way to mitigate financial instability - the FIH: Financial Instability Hypothesis — of a capitalist economy. The five main propositions of the financial instability Hypothesis are:

$\mathrm{H}_{1}$ : A capitalist economy that presents a sophisticated and complex financial system, in constant evolution, (Wall Street Economy) alternates periods of stability and turbulence/chaos.

$\mathrm{H}_{2}$ : These behaviors are endogenous to the capitalist economy, as they derive from selfish interests and may be created even from stable situations.

$\mathrm{H}_{3}$ : The periods of turbulence/chaos may take on different forms such as: interactive inflation, speculative bubbles, or interrelated debt deflations.

$\mathrm{H}_{4}$ : As these turbulences get settled, they develop their own way of moving about; however, such behavior, soon or later, tends to be reversed, be it by restrictions imposed by institutions or practices, by interventions of policies that affect institutional structures or even by properties of markets self-organization; favorable conditions to the emergence of a new regime of stability would arise.

$\mathrm{H}_{5}$ : It is likely that the new regime of stability is characterized by a low level of economic activity; nonetheless, the selfishness of some agents would be responsible for creating a new expansion cycle, leading to the outbreak of a new speculative wave; as times went on, new regimes of incoherent expansion and disastrous contractions would happen.

On the other hand, Caruana (2010) states: Basel III will bring a safer financial system. In an unintended link to Minsky's thought, the BIS's (2011) text establishes:

Given the scope and speed with which the recent and previous crises have been spread around the globe as well as the unpredictable nature of future crises, it is critical that all countries raise the resilience of their banking sectors to both internal and external shocks. (p. 10)

In other words, the BIS (2011) propose a "geological/seismic" approach, when recommending the creation of resilience to shocks. In contrast, Fazarri and Cynamon (2008) show that, somehow, the American credit crisis could be predictable (see Figure C1). Taking BIS (2011) as a basic guideline, the management of reserves is a first point to be examined. Agénor and Pereira (2011) state that a minimum of liquidity, following the Basel III recommendations, requires an increase of the bank reserves, creating inflationary pressures: 
Indeed, one of the measures envisaged under Basel III - to be phased in starting in 2015 - is to require banks to increase their holdings of liquid assets, by imposing a minimum liquidity coverage ratio (see Basel Committee on Banking Supervision (2010)). It is therefore useful to consider the macroeconomic effects of an increase in the required reserve ratio in our setting. The results are illustrated... depending on whether the policy rate is endogenous or not. In both cases, an increase in the reserve requirement rate lowers the deposit rate and induces households to shift consumption towards the present, thereby increasing aggregate demand and inflationary pressures. (p. 36)

\section{Demand for Money}

It is difficult to measure the informal market, difficult to shape technical progresses and, naturally, changes of economic regimes impose difficulties, temporary or permanent, due to economic or political shocks. Even so, it is easy to find in the literature a function of demand for money in macroeconomic models. From Carvalho, Pires De Souza, Sicsú, Rodrigues De Paula, and Studart (2000, p. 98), follows the next equation:

Equation 1: Demand for money according to Friedman:

$$
\frac{M}{P}=f\left(w, r_{a}, r_{b}, \frac{1}{P} \frac{d P}{d T}, y, u\right)
$$

where $u$ represents: tastes and preferences and other factors that may affect the utility of money. In other words, the $u$ parameter represents a microeconomic concept that influences a macroeconomic model. One future goal of the author's work is to identify the channel(s) that influence(s) the utility from changes in banking regulations.

\section{A Marketing Approach}

Money can be considered as a product. From Hayek (1976):

“...Money does not differ from other products in any way. Therefore, the supply of money would be more effective if made by competition".

The product "money supply" is cash, composed of bills and coins. Cash competes with many other products and/or services that perform the function of means of payment, such as cards (credit and debit), the check book, and the stamps (food and transportation, for example). Their comparative advantages: to have discharging power and mandatory use; and exercise a preference for privacy, since all digital money such as electronic cards has some kind of identification.

\section{Money: product or service}

Cash is a product supplied by the Brazilian Central Bank. It is not a service. Cash is tangible and is not customized by client: It is a mass product ${ }^{2}$. In this sense, electronic cards (debit and credit cards, as main examples) can be considered services rendered by financial institutions.

\section{Porter}

According to Porter (1980) strategic successful companies follow defined behavioral patterns that may be summarized in three generic strategies (the sources of competitive advantage over the competitors):

(1) Leadership based on costs has lower costs than the competition;

(2) Differentiation: create a product or a service to be seen in the industry as unique;

(3) Focus: to combine both strategies focusing on a specific target.

\footnotetext{
1 “ ... between banks that are interested in preserving the good quality of its product, that is, the value of the money it issues. The currencies that keep their value stable in the long term would win the competition...". In Hayek's words: “... it seems that, in this circumstance, the mere desire of profit could already produce better money than that issued by the government...".

${ }^{2}$ From Berry and Parasuraman (1995, p. 113): “...Services differ from products, mainly, by their intangibility. A product is an object, a thing. A service, in essence, is a performance. The non-physical essence of a service has great implications on the way clients of services form their opinions and how those that do the marketing of services approach their task... ".
} 
Following this approach, there is a competitive advantage for cash, for it is the only option of mandatory use. There are potential competitors, there are substitutes, the buyers are people, and there are suppliers of expressive strength, which are the suppliers of raw material for paper money. Cash money can be considered as a means of payment that competes with other means of payment according to the preference of people.

\section{Money: Product's Characteristics}

\section{Safety}

With respect to the safety aspect, where is the risk of theft, the advantages of the credit card are not evident and, according to Banco Central Do Brasil (2000-2004): "In case of loss or theft, the holder is in a similar situation as if it were cash, as the amount in the card will be lost". On the other hand, there is the risk of cloning of electronic cards.

\section{Absence of Legacy Problem}

There is no legacy problem: paper money can, technically, replace electronic cards, which are dependent to the energy supply.

\section{The Third Party Dependence}

Paper money is not dependent on additional conditions to close a deal, since they do not depend on internet connections, consultations, or other confirmations. In a parallel drawn with the Internet, intelligence is not on the web, but in the buyer and seller. Even with Consumer-to-Consumer (C2C) transactions, electronic alternatives require a certain dependency—Refer to Takahashi (2000).

\section{Diffusion of Innovations and Product Adoption Concepts}

According to Kotler and Armstrong (1993), an innovation can refer to any product, service, or idea that is perceived by someone as new, although innovations take time to diffuse within society. There are five stages to the adoption of a new product and five other characteristics that determine the innovation rate.

Adoption:

(1) Awareness: The consumer becomes aware of the innovation, but lacks more information about it;

(2) Interest: The consumer is stimulated to search for more information about the innovation;

(3) Evaluation: The consumer considers if it is valuable to try the innovation;

(4) Trial: The consumer experiments with the innovation on a small scale in an attempt to better evaluate its value;

(5) Adoption: The consumer decides to use the innovation regularly.

Innovation rate:

(1) Relative advantage: level by which the product seems to be superior to others;

(2) Compatibility: level by which the new product becomes compatible to the values and experiences of individuals in a community;

(3) Complexity: level of relative difficulty of comprehension or utilization of the product;

(4) Divisibility: level by which the product can be tried during a limited period;

(5) Communication: level by which the results of the utilization of the product are observed or described by third parties. 


\section{Macroeconomic Approach versus Marketing Approach}

There are two approaches referenced to focus on demand for money: macroeconomic and marketing. From the macroeconomic approach, there are models to predict money supply and M1. From a marketing perspective, it can be inferred that potential technological innovations may alter the current scenario.

In the marketing approach, cash has been considered as a product: It is shown that cash competes against many other resources for the preference of the user as means of payment, and that the choice of the means of payment is motivated by the client's convenience, despite the economic segment to which it belongs.

The outstanding aspect is that the strictly monetary assets - money supply and M1 — continue to grow, and the consumer continues to have options with which to manage these assets, be it through money supply or electronic means. According to this, MS and M1 can be considered proportional to GDP, therefore it is only necessary to evaluate how much time it is needed for the GDP to increase and, consequently, MS and M1 will do likewise.

Last but not least, for Sloterdijk (1999), contrary to what was expected, the revolution did not come from the working class but from science and technology. In other words, innovation leads GDP and Money growth.

\section{Data and Methodology}

To evaluate the changes in behavior in the basic series studies, its variation as return is calculated. Initially, daily money supply, banking reserves, and annual inflation announced monthly series have been chosen, as shown in Table 1.

Table 1

Main Series

\begin{tabular}{|l|l|l|l|}
\hline Series & Acronym & Source & Period \\
\hline Daily money supply & MS & BCB 1780-Paper money issues & from 1994 to 11/30/2011 \\
\hline Daily reserves & DR & BCB 1781-BM-Banking reserves & from 1994 to 11/30/2011 \\
\hline Monthly reserves & MR & BCB 1781-BM-Banking reserves & from 1994 to 11/30/2011 \\
\hline Monthly inflation & IPCA & IPEADATA & from 1994 to Dec/2011 \\
\hline
\end{tabular}

Example: $R t=\operatorname{Ln}(M S t / M S t-1)$, where $M S$ is the daily money supply and $R t$ is the logarithmic return between daily closing values. An index price from June 1994, equal to 100, has been taken as a base for the monthly inflation, and the inflator/deflator can be recalculated by month. In order to delimitate distinct conjunctures, a methodology for identifying sudden changes in variance is utilized: The discrete changes in conditional variance are determined by the ICSS algorithm - Iterated Cumulative Sum of Squares - from Inclán and Tiao (1994). The temporal series presents a stationary variance over the initial period. A sudden change in variance occurs some time later, possibly caused by some political and/or economic shock. The variance becomes stationary again, at another level, until another sudden change occurs. This process is repeated creating a temporal series of observations with an unknown number of sudden changes in variance.

Equation 2: AR/GARCH equations to identify sudden changes in the unconditional volatility:

$$
\begin{aligned}
\Delta r_{t} & =A_{0}+A \Delta r_{t-1}+u_{t},(\text { Model AR(1)) } \\
v_{t} & =C+p v_{t-1}+q u_{t-1}^{2}+\text { Lev } I_{t-1} u_{t-1}^{2}
\end{aligned}
$$

Conditions: $u_{t}=\left(v_{t}\right)^{0.5} e_{t} ; e_{t}=t\left(\mu=0 ; \sigma^{2}=1 ; g l=D\right)$ (Distribution $t$-student) $I_{t}=1$ if $u_{t}<0 I_{t}=0$ if $u_{t} \geq 0$.

The coefficients referred to the AR (1) equation of the average: $A_{0}$ is constant in the equation of averages; 
$C$ is constant in the conditional variance equation; $Q$ is the order of residues; $P$ is the order of the conditional variance; $L e v$ is the leverage coefficient, and $D$ is the degree of freedom of the distribution $t$ that models the return series. After that the ICSS algorithm is applied, adapted from Inclán and Tiao (1994) in Regression Analysis of Time Series (RATS) version 4.3.0. For basic references of ARCH and GARCH, it can be referred to Engle (1982) and Bollerslev (1986).

It is studied the variance of a given sequence of observations retrospectively, in order to use all the information on the series to indicate the points of variance change. Let:

$$
C_{k}=\sum^{k} \varepsilon_{t}^{2}, k=1, \ldots, T
$$

be the cumulative sum of squares of a series of uncorrelated random variables with mean zero and variance $\sigma_{t}^{2}$, $t=1,2, \ldots, T$. Let:

$$
D_{k}=\left(C_{k} / C_{T}\right)-k / T \text {, where } k=1, \ldots, T \text { and } D_{0}=D_{T}=0
$$

The plot of $D_{k}$ against $k$ will oscillate around zero for series with homogeneous variance. When there is a sudden change in variance, the plot of $D_{k}$ will exhibit a pattern going out of some specified boundaries with high probability. These boundaries can be obtained from the asymptotic distribution of $D_{k}$ assuming constant variance.

Let $k^{*}$ be the value of $k$ at which $\max k\left|D_{k}\right|$ is attained if the maximum absolute value exceeds a pre-determine boundary, concluding that there is a change point near $k^{*}$ and estimate $k^{*}$ as an estimate of the change point.

\section{Tests and Results}

\section{Money Supply}

The main analysis comprehends the period between 2000 and 2005. Significant changes have not been observed in the variance of the period analyzed, except for after 2002, beginning of a crisis on the eve of the 2002 presidential election, as shown in Table 2.

Table 2

Unconditional Volatility of Daily Money Supply Between January/2000 and November/2005

\begin{tabular}{lll}
\hline Beginning & End & Volatility \\
\hline $01 / 04 / 2000$ & $01 / 05 / 01$ & $1.343 \%$ \\
$01 / 08 / 2001$ & $07 / 02 / 02$ & $1.138 \%$ \\
$07 / 03 / 2002$ & $07 / 15 / 02$ & $3.697 \%$ \\
$07 / 16 / 2002$ & $11 / 10 / 05$ & $1.112 \%$ \\
\hline
\end{tabular}

Note. Source: BCB, time series. Hint: Lowest volatility during the Lula Period, and a high volatility during July 2002 (confidence crisis, before presidential elections of 2002).

\section{Means of Payment Growth}

Contrary to inflationary times (Garcia, 1993) ${ }^{3}$, there is a possible indication of informal GDP growth: the increase of money supply in relation to GDP. This occurs despite the ever propagated use of electronic money, such as credit cards. The growth of the means of payment in relation to the GDP is evident, according to Figure 1.

\footnotetext{
3 "The monetary base is bare, that is, after a period of decades of inflation, with a significant increase during the last years, people have learned to keep only the strictly necessary as money. The rest goes to currency indexed funds".
} 


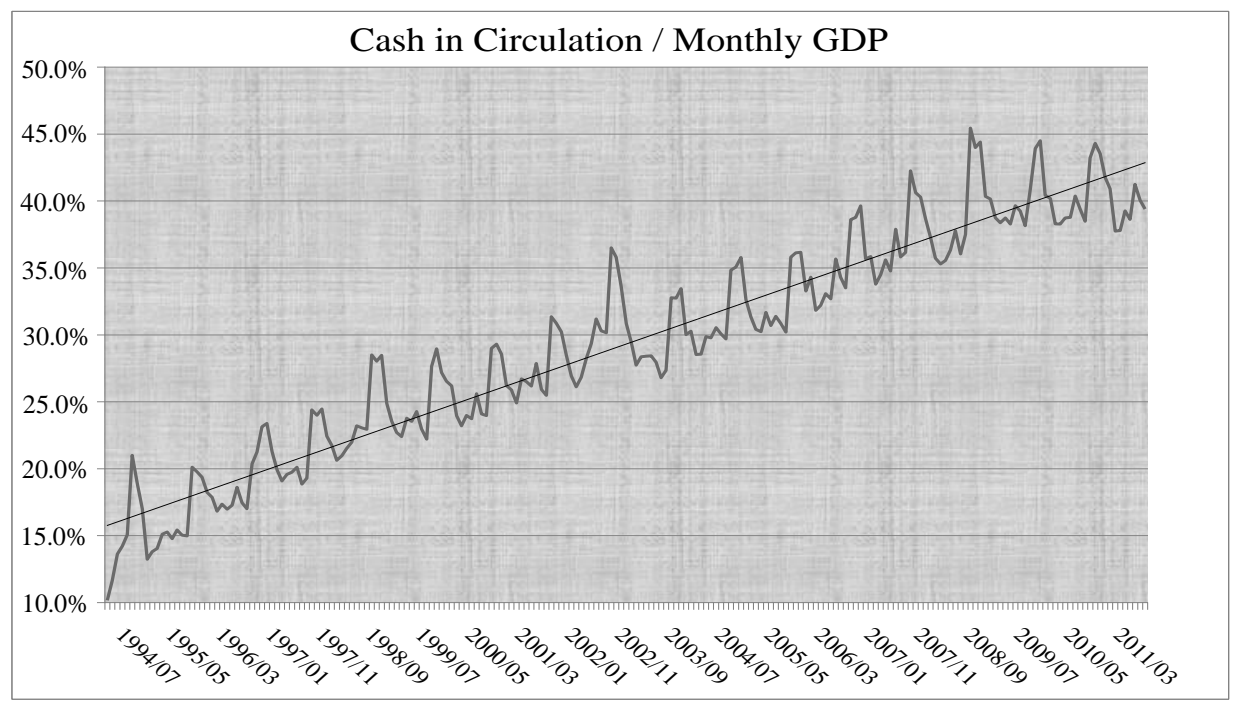

Figure 1. Relative growth of the money supply relative to the GDP. Source: BCB, time series. Hint: Significant increase in the use of cash money, in spite of the simultaneous increase of electronic money.

\section{Banking Reserves}

Figures 2 and 3 and Tables 3 and 4 indicate that there are a higher number of unconditional volatility levels of daily banking reserves, compared to monthly volatility, while Figures 4 and 5 reveal the grows of credit, and the decrease of importance of banking reserves.

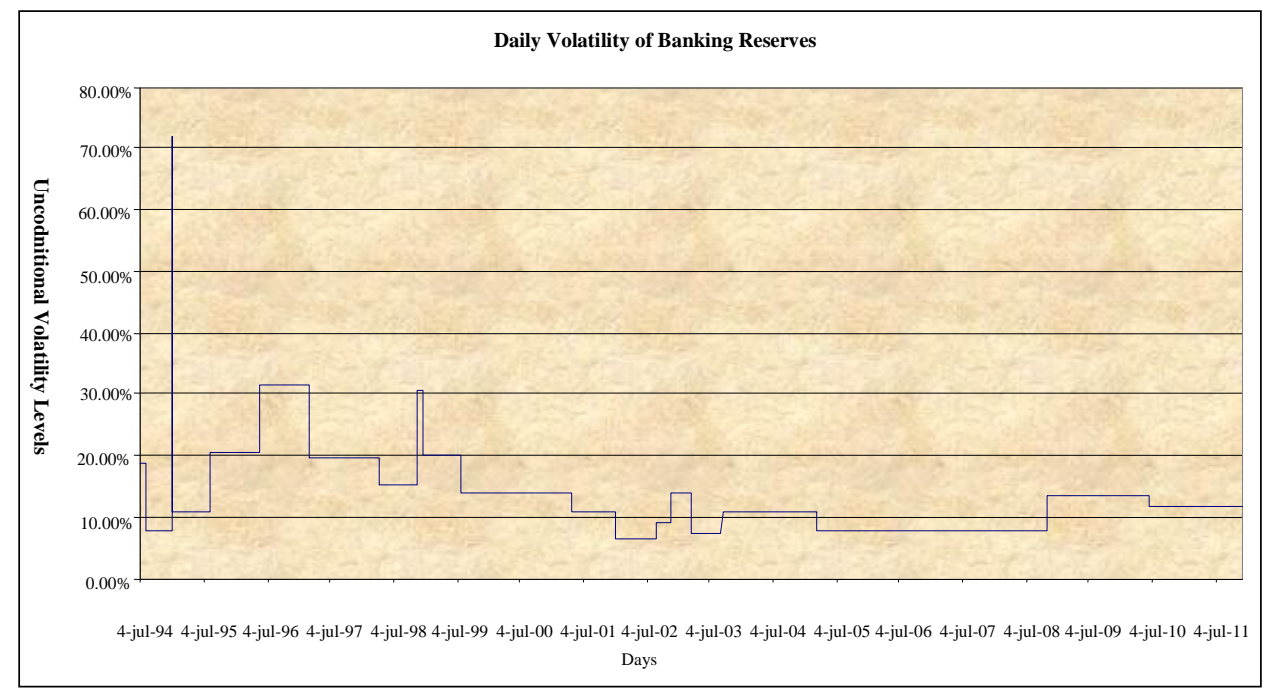

Figure 2. Daily levels of banking reserves volatility.

Table 3

Daily Unconditional Volatility Levels of Banking Reserves

\begin{tabular}{llllllll}
\hline Interval & Initial date & Final date & Volatility & Interval & Initial date & Final date & Volatility \\
\hline 1 & 5-jun-94 & 5-aug-94 & $18.91 \%$ & 11 & 29-jul-99 & 23-apr-01 & $14.11 \%$ \\
2 & 8-aug-94 & 27-dec-94 & $7.88 \%$ & 12 & 24-apr-01 & 8-jan-02 & $10.91 \%$ \\
3 & 28-dec-94 & 30-dec-94 & $71.93 \%$ & 13 & 9-jan-02 & 30-aug-02 & $6.49 \%$ \\
4 & 2-jan-95 & 3-aug-95 & $10.8 \%$ & 14 & 2-sep-02 & 28-nov-02 & $9.10 \%$ \\
5 & 4-aug-95 & 24-may-96 & $20.67 \%$ & 15 & 29-nov-02 & 20-mar-03 & $14.07 \%$ \\
\hline
\end{tabular}


(Table 3 continued)

\begin{tabular}{lllllllc}
\hline Interval & Initial date & Final date & Volatility & Interval & Initial date & Final date & Volatility \\
\hline 6 & 27 -may-96 & 28 -feb-97 & $31.60 \%$ & 16 & 21 -mar-03 & 12-sep-03 & $7.37 \%$ \\
7 & 3 -mar-97 & 17 -apr-98 & $19.70 \%$ & 17 & 15 -sep-03 & 17 -mar-05 & $10.64 \%$ \\
8 & 20 -abr-98 & 10 -nov-98 & $15.43 \%$ & 18 & 18 -mar-05 & 29 -oct-08 & $7.80 \%$ \\
9 & 11 -nov-98 & 21 -dec-98 & $30.78 \%$ & 19 & 30 -oct-08 & 10 -jun-10 & $13.57 \%$ \\
10 & 22 -dec-98 & 28 -jul-99 & $19.92 \%$ & 20 & 11 -jun-10 & 29-nov-11 & $11.59 \%$ \\
\hline
\end{tabular}

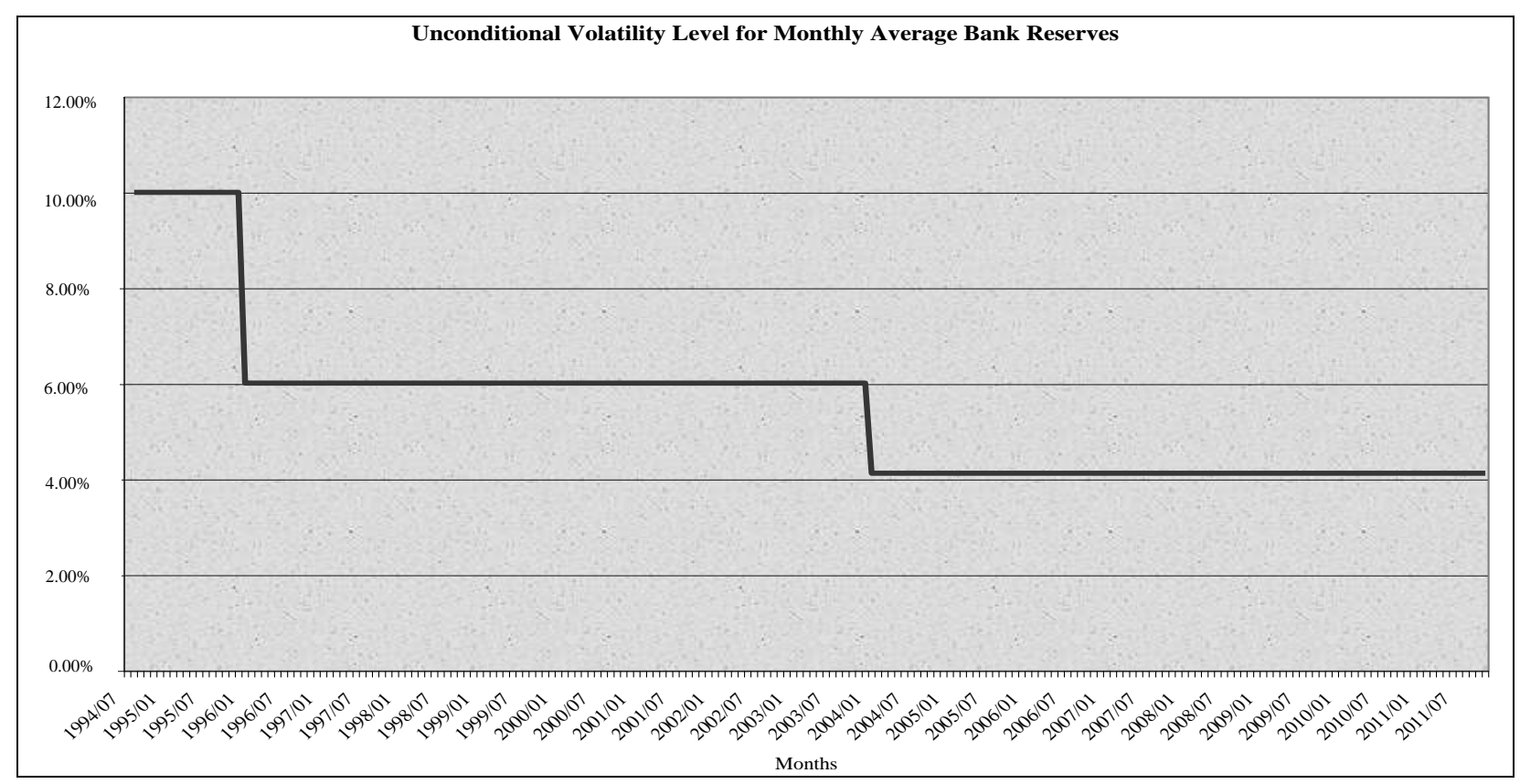

Figure 3. Unconditional volatility of monthly banking reserves. Source: BCB time series. Hint: Lowest volatility since 2004, not affected by the international financial crisis.

Table 4

Banking Reserves: Unconditional Volatility Levels Since the Beginning of Plano Real

\begin{tabular}{lll}
\hline Year/Initial month & Year/End month & Volatility level \\
\hline $1994 / 08$ & $1995 / 12$ & $10.01 \%$ \\
$1996 / 01$ & $2003 / 12$ & $6.03 \%$ \\
$2004 / 01$ & $2011 / 10$ & $4.14 \%$ \\
\hline
\end{tabular}

\section{Inflation: Volatility Levels}

Figure 6 and Table 5 exhibit the result of the monthly unconditional volatility for the monthly inflation, measured by IPCA (The extended consumer price index).

\section{Correlations}

The correlation between monthly reserves and monthly inflation is $-17.8 \%$ during the entire period (July, 1994 to Dec, 2011), i.e., the overall correlation is negative, as shown in Table 6.

Applying the Granger causality test, a relation is found in lags 6 to 8 between monthly inflation and monthly banking reserves. On the other hand, there is a relation in lag 12 and 13 for banking reserves being dependent to inflation. Another evidence of correlation between inflation and banking reserves is a multivariate GARCH test, which indicates that a multivariate GARCH-with monthly inflation and banking reserves - shows in Table 7, two dependent GARCH models. 


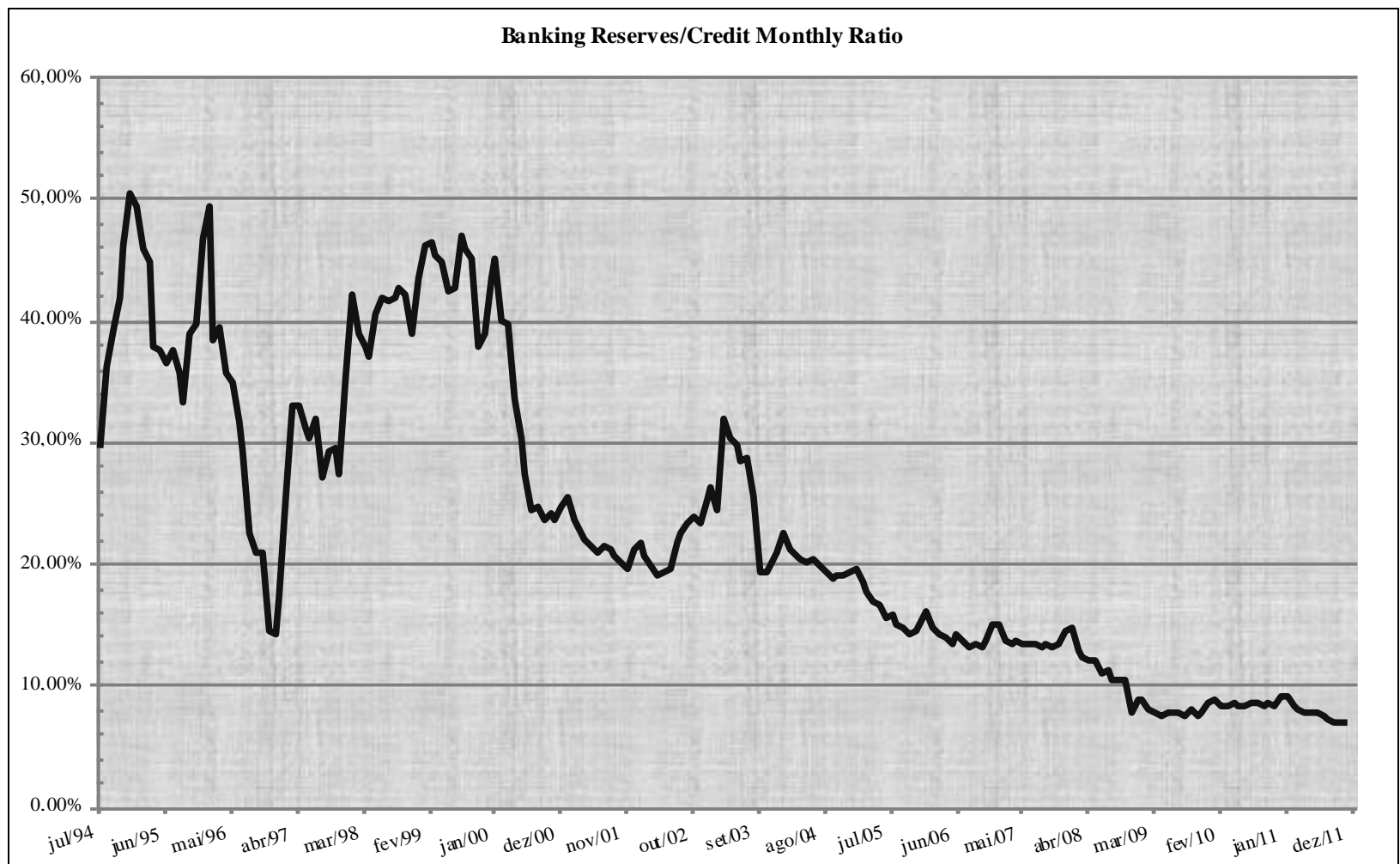

Figure 4. Decrease of the banking reserves/credit to individuals ratio. Source: BCB, time series. Hint: decreasing relevance of banking reserves, from July/94 on.

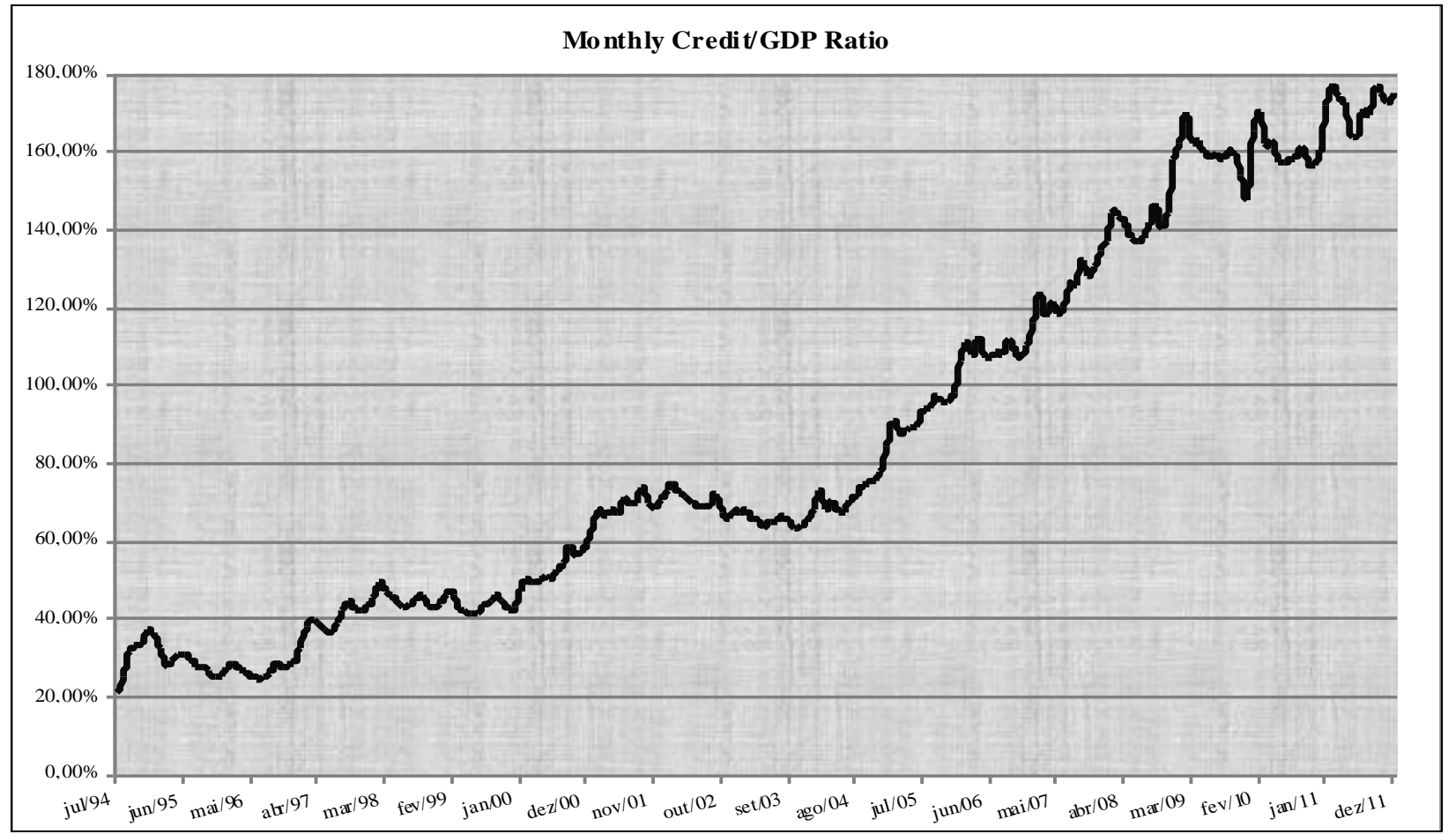

Figure 5. Credits/Monthly GDP. Source: BCB, time series. Hint: Increasing relevance of Credit $\Leftrightarrow$ decreasing relevance of banking reserves. 


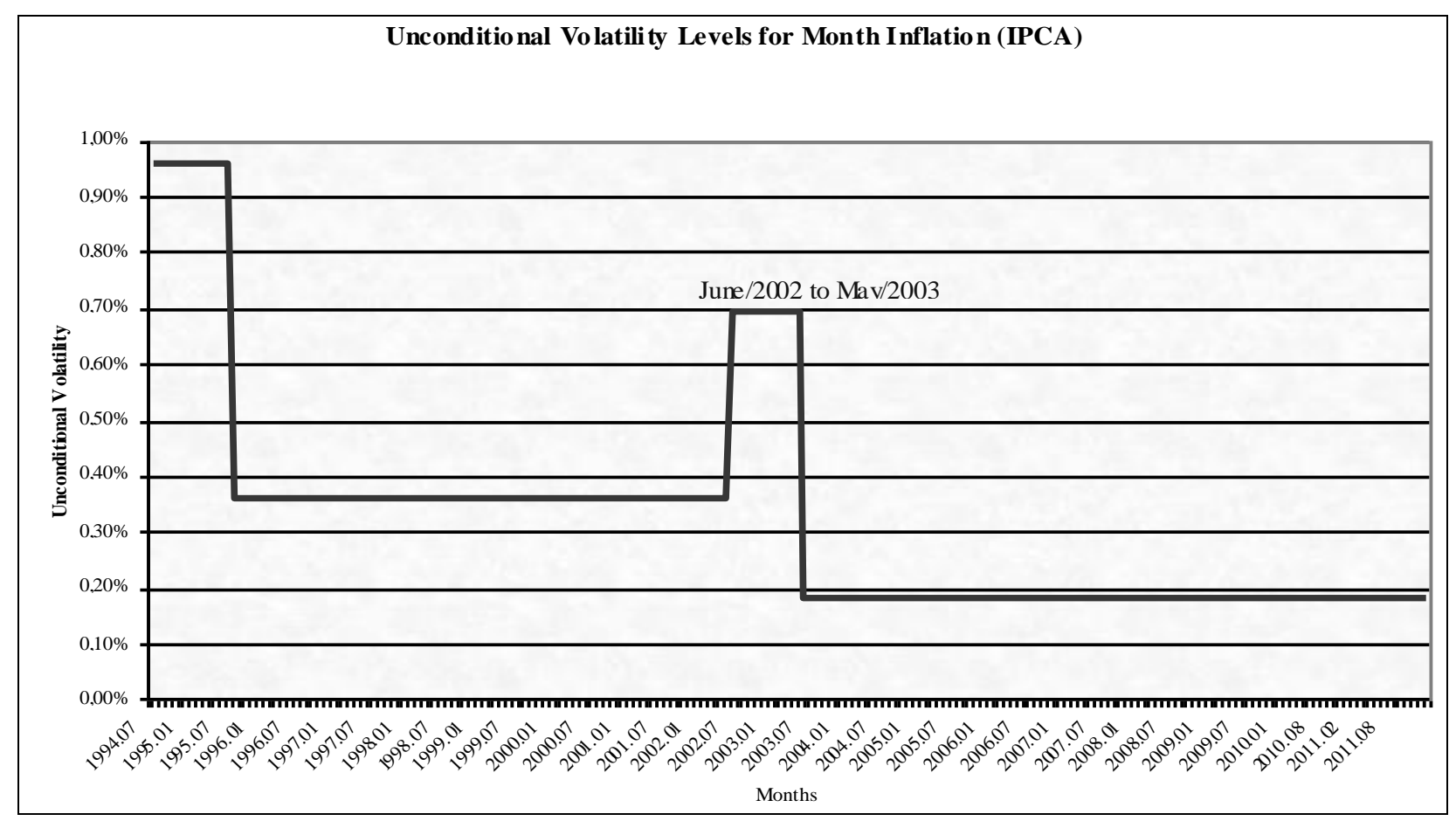

Figure 6. Unconditional volatility levels for inflation during the Plano Real.

Table 5

Volatility Levels for Inflation During Plano Real

\begin{tabular}{lll}
\hline Year/Beginning month & Year/End month & \\
\hline 1994.07 & 1995.07 & $0.96 \%$ \\
1995.08 & 2002.05 & $0.36 \%$ \\
2002.06 & 2003.05 & $0.69 \%$ \\
2003.06 & 2011.11 & $0.18 \%$ \\
\hline
\end{tabular}

Note. Source: Working Paper. Hint: Lowest unconditional volatility level after the Beginning of the first President Lula period.

Table 6

Regression Statistics for Inflation From Banking Reserves (1994 to 2011)

\begin{tabular}{llllllr}
\hline & Coeficients & Standard error & Stat $t$ & $P$ value & $95 \%$ inferior & $95 \%$ superior \\
\hline Intersection & -0.000161827 & 0.000347944 & -0.46509 & 0.642355 & -0.000847815 & 0.000524162 \\
Variable X 1 & -0.009791452 & 0.003768097 & -2.59851 & 0.010039 & -0.017220432 & -0.002362473 \\
\hline
\end{tabular}

Table 7

Multivariate GARCH for Monthly Inflation and Monthly Banking Reserves

\begin{tabular}{llllllllll}
\hline Coefficient & Value & Std Error & $t$-value & $p$-value & Coefficient & Value & Std Error & $t$-value & $p$-value \\
\hline C $(1)$ & $-1.93 \mathrm{E}-05$ & $1.88 \mathrm{E}-04$ & -0.1027 & 0.918277 & ARCH $(1 ; 1,1)$ & $1.93 \mathrm{E}-01$ & $4.63 \mathrm{E}-02$ & 4.1567 & $4.76 \mathrm{E}-05$ \\
$\mathrm{C}(2)$ & $1.03 \mathrm{E}-02$ & $5.07 \mathrm{E}-03$ & 2.0303 & 0.043633 & ARCH $(1 ; 2,1)$ & $-2.77 \mathrm{E}-02$ & $1.64 \mathrm{E}-02$ & -1.688 & 0.092952 \\
$\mathrm{~A}(1,1)$ & $3.06 \mathrm{E}-07$ & $2.09 \mathrm{E}-07$ & 1.4632 & 0.144959 & ARCH $(1 ; 2,2)$ & $2.26 \mathrm{E}-01$ & $6.22 \mathrm{E}-02$ & 3.6343 & 0.000353 \\
$\mathrm{~A}(2,1)$ & $5.90 \mathrm{E}-07$ & $1.16 \mathrm{E}-06$ & 0.5078 & 0.612152 & GARCH $(1 ; 1,1)$ & $7.94 \mathrm{E}-01$ & $4.14 \mathrm{E}-02$ & 19.1932 & 0 \\
$\mathrm{~A}(2,2)$ & $5.87 \mathrm{E}-04$ & $1.94 \mathrm{E}-04$ & 3.0249 & 0.002808 & GARCH $(1 ; 2,1)$ & $9.65 \mathrm{E}-01$ & $1.88 \mathrm{E}-02$ & 51.4784 & 0 \\
$\mathrm{ARCH}(1 ; 1,1)$ & $1.93 \mathrm{E}-01$ & $4.63 \mathrm{E}-02$ & 4.1567 & $4.76 \mathrm{E}-05$ & GARCH $(1 ; 2,2)$ & $7.09 \mathrm{E}-01$ & $6.26 \mathrm{E}-02$ & 11.3232 & 0 \\
\hline
\end{tabular}


Finally, Figure 7 compares savings, banking reserves, and call deposits, and shows the decreasing relevance of the banking reserves.

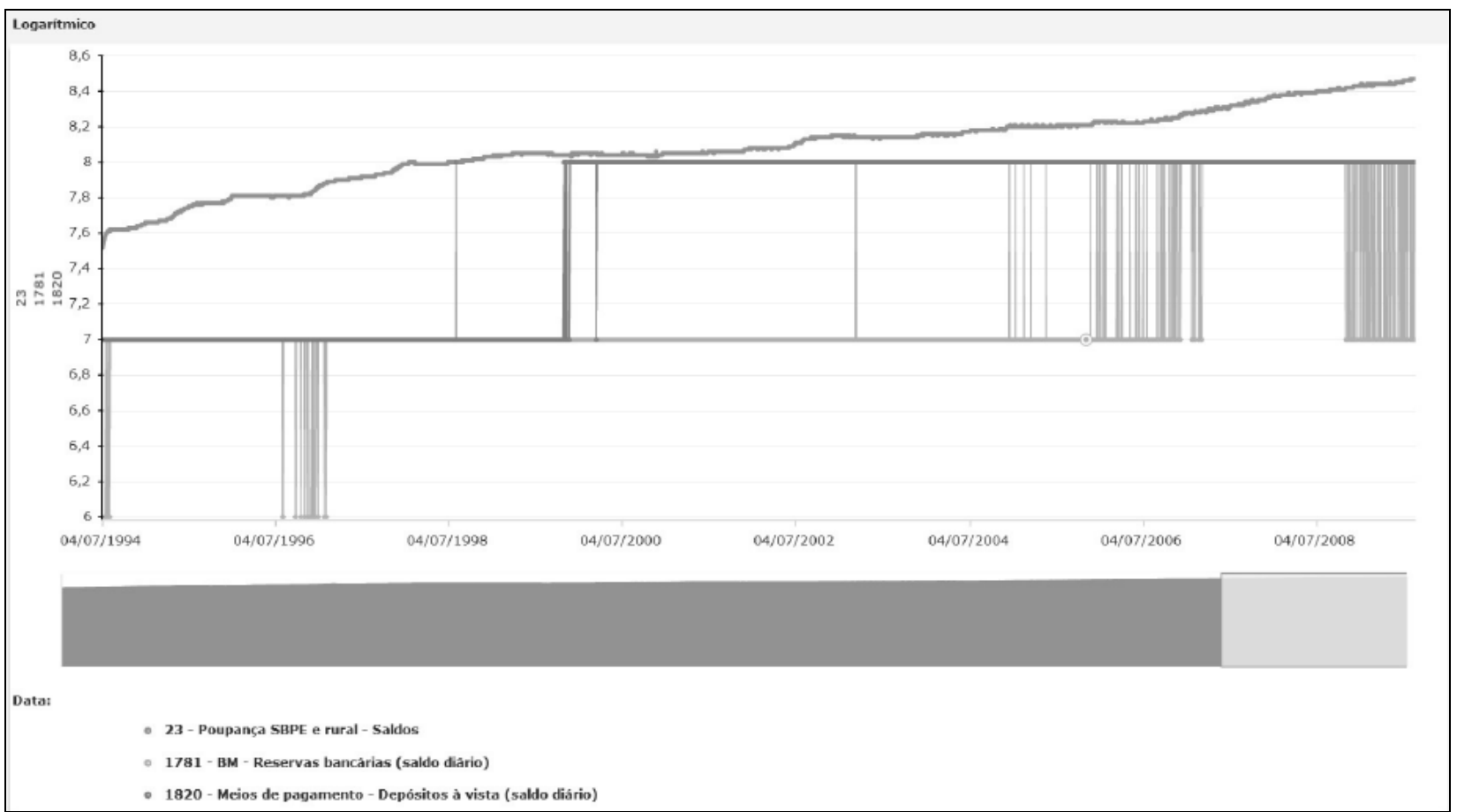

Figure 7. Level of savings, reserves, and call deposits. Source: BCB, time series-automatic log generation. Hint: low relevance of banking reserves: Once displayed in logarithmic scale, it is possible to visually inspect that the variance of reserves does not influence the increase of call deposits (Logarítmico $=$ Logarithm).

Data: 23 - Poupança SBPE e Rural (saldos) = SBPE and Rural Savings (Balances);

$1781-$ BM - Reservas bancárias (saldo diário) = Banking Reserves (daily balance);

1820 - Meios de pagamento - Depósito à vista (saldo diário) = Means of Payment - Call Deposits (Daily balance).

\section{Conclusions}

This text attempted to evaluate the convergence of objectives of a Central Bank, such as inflation targeting, bank supervising, and financial inclusion, under the recommendations of the Basel III agreement. The first results do not show evidences of destructive interference, among the activities of the Brazilian Central Bank, starting in July 1994 and finishing in 2011, during the regency of the Plano Real (Brazilian Economic Stabilization Plan).

The Basel agreement is a compulsory compliance and this reason in itself is enough to make it a necessary condition for stabilizing a country's finance, although not a sufficient one, for two basic reasons. First, each country has specific characteristics. Second, an agreement/contract is clearly time frame inconsistent with day-to-day negotiation, as seen from Williamson (2000). The BIS (2011) document makes reference to a global conjuncture and, evidently, does not go into specific details of each country. It is important to point out that the Brazilian Central Bank, for acting in the traditional role of monetary authority as well as supervising the Brazilian financial system, necessarily has a dual objective. Therefore, its credibility depends on the simultaneous fulfillment of both objectives. The use of banking reserves as a regulatory instrument—following 
Basel III — creates a clear link between both objectives. Also, the possibility of over regulation is a new issue; an item not listed as possible source for the financial crisis (see Appendix Figure D1)

The hypothesis of positive variance of reserves implying the increase of inflationary pressures - during the selected period, i.e., from the Plano Real up to Dec., 2011-is rejected. On the one hand, a significant daily variance of banking reserves has been found, not related to inflation. On the other hand, there are clearly distinct levels of unconditional volatility in all series, for instance, by putting together the return series based on the IPCA, which is released monthly, four levels of unconditional volatility for the annual inflation released monthly have been verified, from Plano Real onwards: $0.96 \%$ in the beginning of Plano Real, $0.36 \%$ between August 1995 and May 2003, 0.69\% accredited to the trust crisis on the eve of the Lula Government election, and $0.16 \%$ (the lowest level of volatility) from June 2003 up to the end of the period. Moreover, the correlation between monthly reserves and monthly inflation was negative (-17.8\%) during the test period (from July 1994 to Dec., 2011).

In Figure 7 (level of savings, reserves, and call deposits) and in Figure B2 in Appendix (decrease related to savings), it can be verified that the daily savings balance has increased in relation to the reserves balance, which suggests an increasing irrelevance of the reserves in relation to the savings. This relation can be seen in Figure B2 in Appendix. From a different perspective, the savings/M1 ratio has always decreased until the worsening of the crisis in 2008.

No evidences of interference have been found among the objectives of the Central Bank. The evolution of financial inclusion can be measured by the increase of traditional financial assets (savings and assets funds). Yet, it could be better measured by the constant increase of the money supply as well as the impressive increase on the number of credit cards, combined with possible restrictions on the increase of financial assets: limit superior which is the need for working capital (store owners daily liquidity) and the high level of the interest rates practiced in the country. In another view, the reader ought to be aware that, differently from clearly measurable objectives such as inflation targeting and Basel agreement, the finance inclusion concept still lacks a unique definition.

Agénor and Pereira (2011) would be chosen as a first reference for testing if Central Bank could keep up with the commitment of fulfilling three objectives simultaneously: inflation targeting, bank supervising under Basel III, and financial inclusion. In the research's next stage, M. Areosa and W. Areosa (2006) ${ }^{4}$ could also be considered and alternative metrics will be sought for the evaluation of the financial inclusion evolution.

The case in which the increase of reserves decreases the bank deposits, encourages consumption and creates inflationary pressures could be the object of future multidisciplinary investigation. Readers shall take note that this is a possible scenario that can happen in a conjuncture other than the one chosen (Jul, 1994 to Dec., 2011): low inflation, high interest rates, high fiscal taxes, and (counter-intuitive) growth of the use of cash (non-electronic) money. The future analysis may require competencies pertinent to prospective finance and consumer behavior (marketing). In this approach, money (any kind of) can be treated as a product.

\section{References}

ABECS. (2011). Eletronic card use in Brazil (Uso de cartões eletrônicos no Brasil). Retrieved from http://www.abecs.org.br AFI. (2010). Taking financial inclusion to the next level. AFI: Global Policy Forum Report.

\footnotetext{
4 “... under this 'inequality expanded' objective, an optimal monetary policy can no longer simultaneously stabilize the output gap and inflation since it has to take the effects of inequality into consideration, even when inequality has no impact on inflation".
} 
Agénor, P. R., \& Pereira, L. A. S. (2011). Macroprudential regulation and the monetary transmission mechanism. Brasília: Banco Central do Brasil, Working Paper 254.

Albuquerque, P. (2001). The economic impacts of CPMF (Os Impactos Econômicos da CPMF: Teoria e Evidência). Brasília: Banco Central do Brasil, Working Papers Series 21.

Alves, S. D. (2006). Microfinance: The Brazilian credit democratization through Central Bank actions (Microfinanças: democratização do crédito no Brasil: atuação do Banco Central). Brasília, Brasil: Banco Central do Brasil.

ANEFAC. (2011). Credit cards interest rates (Juros do Cartão de Crédito). Retrieved from http://www.anefac.com.br/PesquisaJuros.aspx

Areosa, M., \& Areosa, W. (2006). The inequality channel of monetary transmission. Brasília: Banco Central do Brasil Working Paper 114.

Banco Central Do Brasil. (2000-2004). Cash on circulation: Reports (Departamento do Meio Circulante: Relatórios). Brasil: Rio de Janeiro.

Banco Central Do Brasil. (2004). Comments on cash circulation evolution (Uma Nota sobre a Evolução do Meio Circulante). Brasil: Rio de Janeiro.

Banco Central Do Brasil. (2005). Means of payment: A diagnosis (Diagnóstico do Sistema de Pagamentos de Varejo no Brasil). Brasil: Brasília.

Banco Central Do Brasil. (2011). Finance inclusion report (Relatório de Inclusão Financeira). Brasil: Brasília.

Berry, L. L., \& Parasuraman, A. (1995). Market services: Competing through quality (Serviços de Marketing: Competindo Através da Qualidade). São Paulo: Editora Maltese.

BIS. (2011). Basel III: A global regulatory framework for more resilient banks and banking systems. Retrieved from http://bis.org/publ/bcbs189.pdf

Bollerslev, T. (1986). Generalized autoregressive conditional heteroskedasticity. Journal of Econometrics, 31, 307-327.

Caruana, J. (2010). Basel III: Towards a safer financial system. Proceedings from 3rd Santander International Banking Conference, Madrid, Spain.

Carvalho, F. J. C., Pires De Souza, F. E., Sicsú, J., Rodrigues De Paula, L. F., \& Studart, R. (2000). Monetary and financial economy (Economia Monetária e Financeira: Teoria e Política). Brasil: Rio de Janeiro, Campus.

Costa Moura, G. (1997). Economic Plan Real upgraded Rio de Janeiro's pour class to middle class (Real Levou os Pobres do Rio para a Classe Média). Rio de Janeiro: O Globo (Newspaper).

DATAFOLHA. (2005). The Brazilians and their money (O Brasileiro e sua relação com o Dinheiro). Brasil: São Paulo.

Engle, R. (1982). Autoregressive conditional heteroskedasticity with estimates of the variance of United Kingdom inflation. Econometrica, 50, 987-1007.

Fazarri, S., \& Cynamon, B. (2008). Household debt in the consumer age: Source of growth-Risk of collapse. Retrieved from http://www.bepress.com/cas/ vol3/iss2/art

FGV-RJ. (2004). Economic barriers to growth. In M. Leitão (Ed.), Economic panorama (Panorama Econômico). Rio de Janeiro, Brasil: O Globo (newspaper).

Garcia, M. (1993). Monetary control under high inflation (O Controle Monetário sob Inflação Alta). Rio de Janeiro: PUC Working Papers.

Hayek, F. (1976). Denationalization of money. London: Institute of Economic Affairs.

Inclán, C., \& Tiao, G. C. (1994). Use of cumulative sums of squares for retrospective detection of changes of variance. Journal of The American Statistical Association, 89, 913-923.

Jevons, W. S. (1875). Money and the mechanism of exchange. London: Routledge and Kegan Paul.

Kotler, P., \& Armstrong, G. (1993). Marketing principles (Princípios de Marketing). Rio de Janeiro: Prentice-Hall.

KPMG. (2009). Never again? Risk management in banking beyond the credit crisis. New York: KPMG.

Lundberg, E. (2011). State banks and directed credit: What differentiates the Brazilian credit market? (Bancos Oficiais e Crédito Direcionado: o que diferencia o mercado de crédito brasileiro?). Brasília, Banco Central do Brasil. BCB Working Paper 258.

Minsky, H. (2008). Stabilizing an unstable economy. New York: McGraw Hill.

Nordhaus, W. D. (1994). Do real output and real wage measures capture reality? The history of lighting suggest not. Cowles Foundation Discussion Paper No. 1078. New Haven, C.T.: Yale University.

Noronha, E. (2003). Perceptions from the Brazilian work market (Informal, Ilegal, Injusto: Percepções do Mercado de Trabalho no Brasil). Revista Brasileira De Ciências Sociais, 18(53), 111-129.

Porter, M. (1980). Competitive strategy: Techniques for analyzing industries and competitors. New York: The Free Press. 
Serra, J. (2013). Sailing against the wind-Homenage to Hirschmann (Navegando contra o Vento-Homenagem a Hirschman). Retrieved from http://www.joseserra.com.br/

Sloterdijk, P. (1999). In the same boat-An hyperpolitic essay (No mesmo Barco: ensaio sobre a hiperpolítica). São Paulo: Estação Liberdade.

Takahashi, T. (2000). Information society in Brasil (Sociedade da Informação no Brasil). Brasília, Brazil: Ministério da Ciência e Tecnologia.

Timbergen, J. (1952). On the theory of economic policy. Amsterdam: North Holland.

Weatherford, J. (2000). The history of money (A História do Dinheiro). São Paulo, Brazil: Editora Negócio.

Williamson, O. E. (2000). The new institutional economics: Taking stock, looking ahead. Journal of Economic Literature, 38(3), 595-613.

Appendix A: Hindrances to Growth

\section{Barriers to Growth}

\begin{tabular}{|c|c|c|c|}
\hline Sector & $\begin{array}{c}\text { Tax } \\
\text { Burden }\end{array}$ & $\begin{array}{c}\text { Basic } \\
\text { Interest } \\
\text { Rates }\end{array}$ & Others* \\
\hline Manufacturing Industry & $56 \%$ & $25 \%$ & $19 \%$ \\
\hline Consumer Goods & $62 \%$ & $29 \%$ & $9 \%$ \\
\hline Capital Gods & $74 \%$ & $17 \%$ & $9 \%$ \\
\hline Real State & $33 \%$ & $41 \%$ & $26 \%$ \\
\hline Intermediary & $52 \%$ & $29 \%$ & $19 \%$ \\
\hline
\end{tabular}

Figure A1. Brazil: Economic barriers to growth. Source: FGV-RJ-2004; ${ }^{*}$ Sum of the answers for the internal political environment, external environment, imbalances of public accounts, lack of industrial policies, and deficient infrastructure.

Tax Handcuffs: Not the interest rate policy, nor the industrial policy. What stops Brazil from growing sustainably is the tax burden. This conclusion was reached after a query from Fundação Getúlio Vargas (FGV) to companies that represent $40 \%$ of the industrial GDP of the country. The businessmen were heard during the month of January: 56\% mentioned the excess of taxes as a main hindrance to economy's expansion.

FGV included the question about the factors that limit the growth during its last industry research, 1,250 companies participated. More than the result, what really surprised was the emphasis given to the tax matter. The subject was mentioned more than twice than that in second place, the level of the basic interest rate (25\%), exactly in the same month that the Central Bank decided to stop the decline path of the Brazilian Basic short term interest rate (SELIC).

The questionnaire presented seven topics that could make the continuous expansion of the national GDP more difficult: aside from the tax burden, the internal political environment, international scenario, the imbalance of the public accounts, the lack of industrial policies, the defective infrastructure, and the interest rates. Those interviewed could choose three options, numbering them from the highest to the lowest in importance.

In 2003 taxes reached $35.5 \%$ of the GDP, the highest level ever reached: tax burden is a very serious problem for the Brazilian companies and for the development. It would be more important than the housing measures, for instance, to rethink the taxes in the home building sector.

Another unexpected finding was the little importance that the big companies give to the industrial policies. This matter was only mentioned as a main hindrance by $3 \%$ of those interviewed. Similar proportions were given to the internal political environment, with 5\%; the international scenario, with $2 \%$; the fiscal imbalance of the State, with 5\%; and the infrastructure problems, with $4 \%$.

The Growth of Electronic Cards can be seen in Figure A2. 


\begin{tabular}{|c|c|c|c|c|c|c|c|}
\hline & & 2000 & 2001 & 2002 & 2003 & 2004 & 2005 \\
\hline & Cards (Millions) & 119 & 151 & 183 & 222 & 277 & 338 \\
\hline & Variation $(\%)$ & & $27 \%$ & $21 \%$ & $21 \%$ & $25 \%$ & $22 \%$ \\
\hline $\overrightarrow{0}$ & Num Transactions (bill io & 1,3 & 1,6 & 1,9 & 2,2 & 2,9 & 3,7 \\
\hline$\theta$ & Variation (\%) & & $23 \%$ & $19 \%$ & $16 \%$ & $32 \%$ & $28 \%$ \\
\hline & Values (Billi ons R\$) & 69,2 & 92,5 & 108 & 132 & 164,1 & 203,2 \\
\hline & Variation (\%) & & $34 \%$ & $17 \%$ & $22 \%$ & $24 \%$ & $24 \%$ \\
\hline & Cards (Millions) & 29 & 38 & 42 & 45 & 53 & 68 \\
\hline$\Longleftrightarrow$ & Variation $(\%)$ & & $31 \%$ & $11 \%$ & $7 \%$ & $18 \%$ & $28 \%$ \\
\hline & Num Transactions (bill io & 0,7 & 0,8 & 1,0 & 1,1 & 1,4 & 1,7 \\
\hline 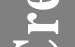 & Variation (\%) & & $14 \%$ & $25 \%$ & $10 \%$ & $27 \%$ & $21 \%$ \\
\hline$)$ & Values (Billions $\mathbf{R} \$$ ) & 49,4 & 63,6 & 73,0 & 88,0 & 101,3 & 123,0 \\
\hline & Variation (\%) & & $29 \%$ & $15 \%$ & $21 \%$ & $15 \%$ & $21 \%$ \\
\hline & Cards (Millions) & 48 & 64 & 82 & 105 & 138 & 171 \\
\hline & Variation $(\%)$ & & $33 \%$ & $28 \%$ & $28 \%$ & $31 \%$ & $24 \%$ \\
\hline 8 & Num Transactions (bill io & 0,2 & 0,4 & 0,5 & 0,7 & 1,1 & 1,4 \\
\hline (1) & Variation $(\%)$ & & $100 \%$ & $25 \%$ & $40 \%$ & $57 \%$ & $27 \%$ \\
\hline e & $\overline{\text { Values (R\$) }}$ & 10,6 & 16,7 & 21,8 & 28,8 & 44,2 & 58,2 \\
\hline & Variation $(\%)$ & & $58 \%$ & $31 \%$ & $32 \%$ & $53 \%$ & $32 \%$ \\
\hline & Cards (Millions) & 42 & 50 & 59 & 71 & 86 & 99 \\
\hline $\mathscr{G}$ & Variation $(\%)$ & & $19 \%$ & $18 \%$ & $20 \%$ & $21 \%$ & $15 \%$ \\
\hline 2 & Num Transactions (bill io & 0,3 & 0,3 & 0,4 & 0,4 & 0,5 & 0,6 \\
\hline 8 & Variation (\%) & & $19 \%$ & $18 \%$ & $20 \%$ & $21 \%$ & $15 \%$ \\
\hline ? & Values (Billions R\$) & 10,2 & 12,2 & 13,2 & 15,2 & 18,6 & 22,0 \\
\hline & Variation $(\%)$ & & $20 \%$ & $8 \%$ & $15 \%$ & $22 \%$ & $18 \%$ \\
\hline
\end{tabular}

Figure A2. Growth of electronic credit cards in Brazil (2000-2005). Source: ABECS (2006).

Appendix B: Financial Inclusion in Brazil

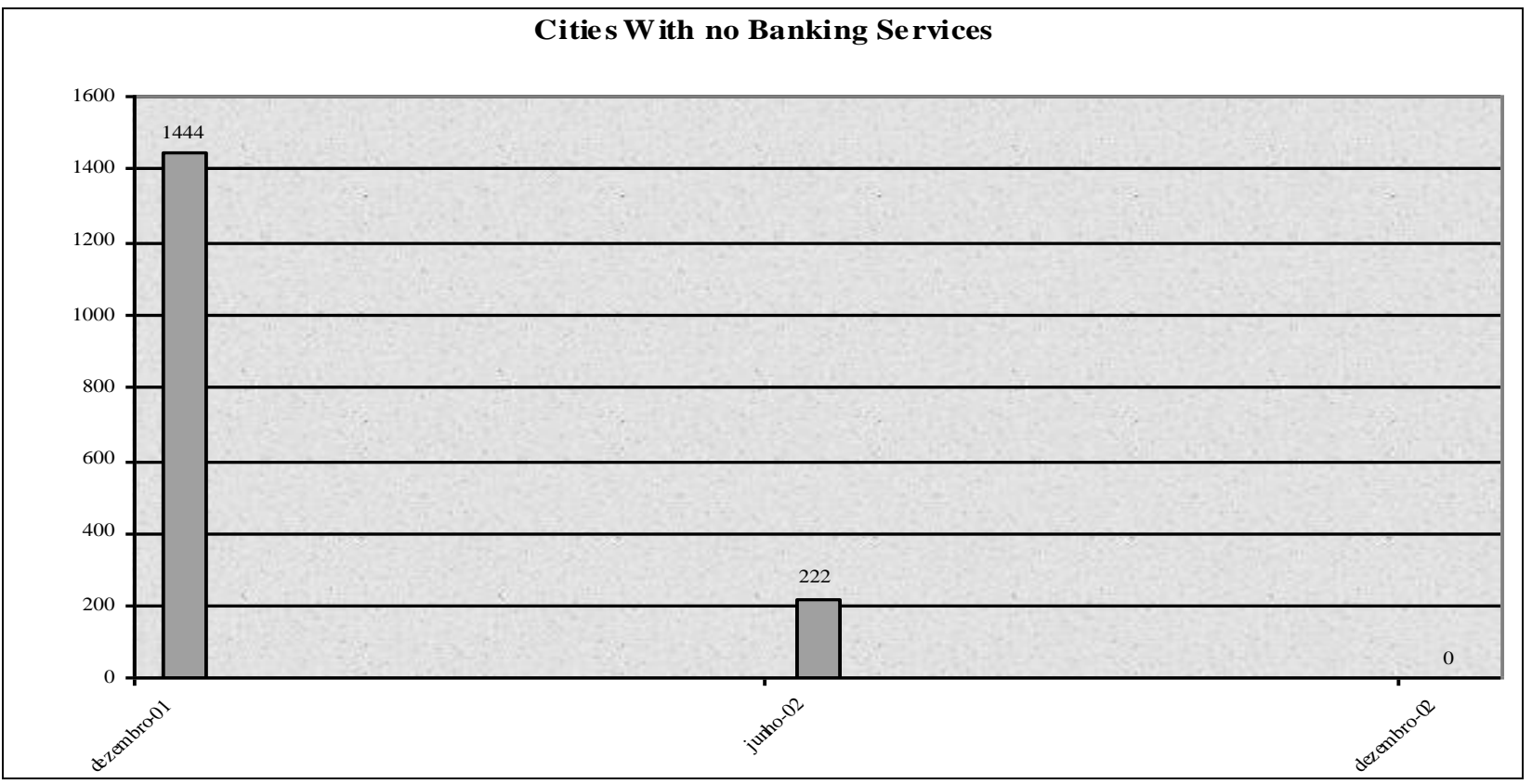

Figure B1. Cities without banks in Brazil. Source: Alves (2006). Hint: indicator for the completeness of supply side for financial services. Refer to AFI (2010). 
Stagnation of savings: The ratio savings/M1 has decreased almost every period of the Plano Real, with reversion starting from July 2008. This can be considered an indication of weak formation of savings.

Lundberg (2011):

An important part of the national financial system is made available through official banks and credit directing BNDES, with direct and on lending operations, is responsible for about $20 \%$ of the SFN credit, and almost all housing and rural credit operations are done by CEF (Caixa Economica Federal) and Banco do Brasil, respectively. The increase in directed credit after the 2008/2009 international crisis enforces the understanding that these credits still have an important role in the Brazilian economy. At that time, the Government tried to assure the continuity of the growth of credit offer through an increase in the operations by official banks, especially BNDES, and via the temporary elevation from $25 \%$ to $30 \%$ of the compulsory investments from rural credit banks (Resolution $\mathrm{n}^{\mathbf{0}} 3.623$, from October 142008 , from CMN - Conselho Monetário Nacional). (pp. 1-2)

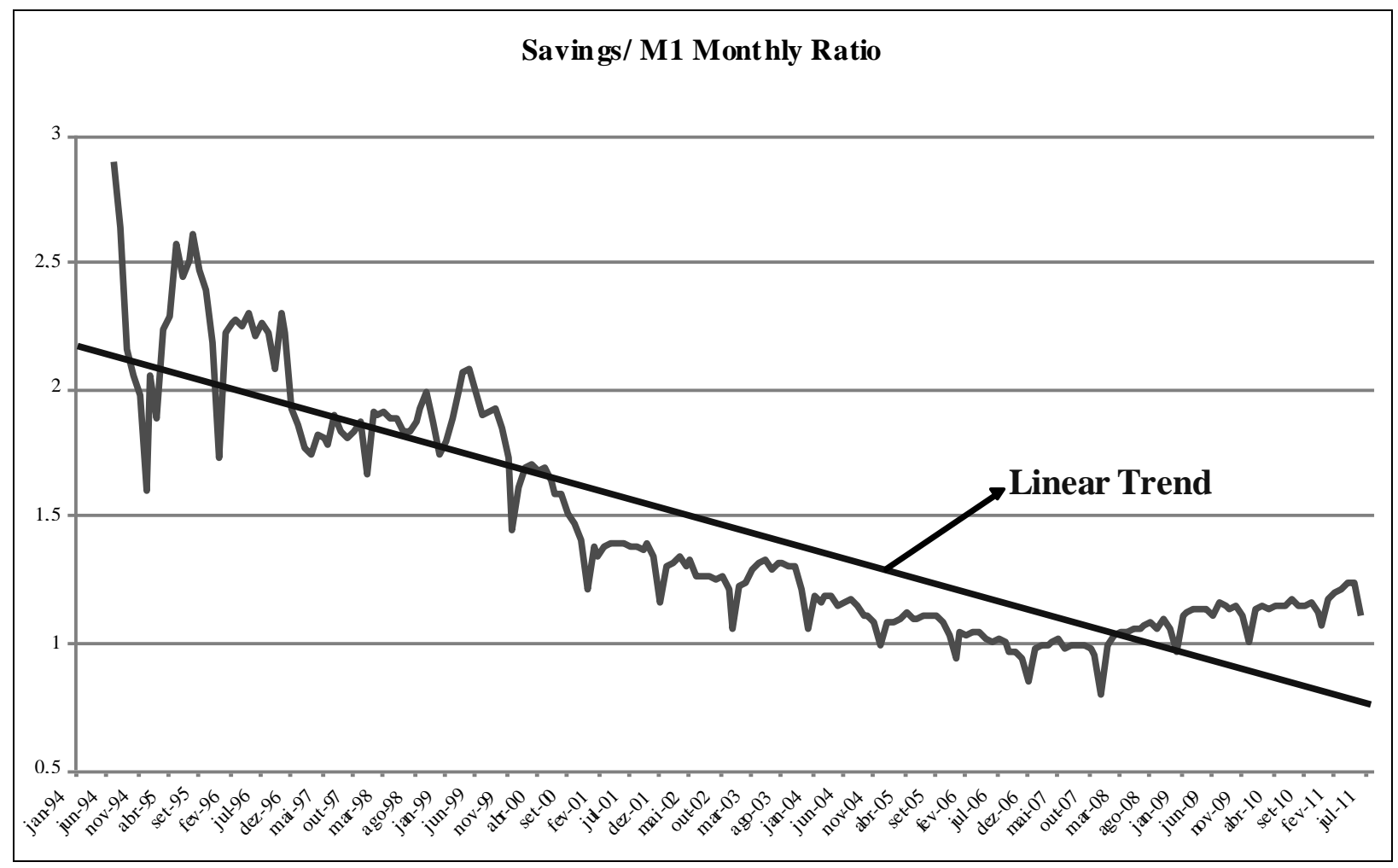

Figure B2. Savings decrease related to M1. Source: BCB time series. Hint: Increasing rate of means of payment related to savings, in a low inflationary conjuncture.

\section{AFI and Basel}

Financial inclusion report. Brazil, is currently an effective member of various international organizations that establish standards for financial systems (Standard Setting Bodies-SSB), as the Basel Committee on Banking Supervision, the Financial Action Task Force (FATF) or GAFI and the Committee on Payments and Settlement System (CPSS). With the purpose of facilitating the coordination with many SSBs for the development of a common agenda related to financial inclusion, the Global Partnership for Financial Inclusion (GPFI) has requested the Brazilian Central Bank to take part in a case study containing questions that could be improved in the context of the mandates of each one of these international organizations. The final work, prepared by the Alliance for Financial Inclusion (AFI), as the Consulting entity for the GPFI, that brings together approximately 80 regulators and supervisors of the financial system from around the world, has counted on the subsidies of representatives of 
supervising entities from the SFN, such as the Brazilian Central bank and the Superintendence of Private Insurance (SUSEP).

AFI (2010). Across countries, regulators have worked to establish an enabling regulatory framework for microfinance institutions. In this task, leaders have been mindful of new standards in the banking landscape, such as the introduction of Basel III capital requirements. It is widely recognized that an enabling regulatory and supervisory approach for microfinance should be simplified but stringent to reflect the unique risks of microfinance, especially the qualitative aspects of corporate governance and risk management. In response to the unique challenges of banking the poor, many countries have established dedicated departments and institutions to provide rigorous on- and off-site supervision of microfinance activities.

Appendix C: Miscellaneous (Example: Evidence of Credit Risk-Personal Expenses in the United States)

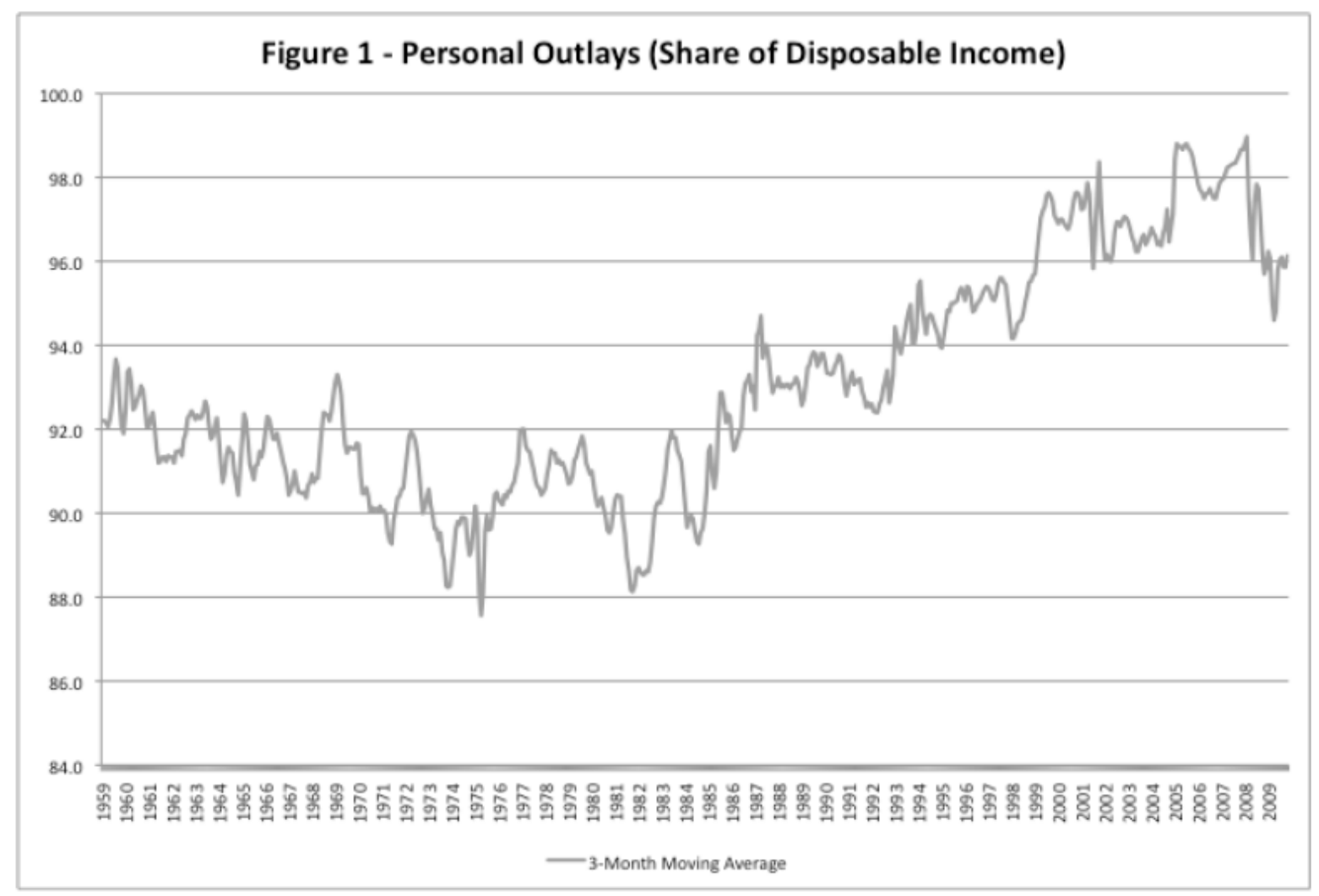

Figure C1. U.S. personal expenses based on income. Source: Fazarri \& Cynamon, 2008.

Table C1

Brazil Road Map (Minimum Parameters for Regulatory Capital According to Basel III)

\begin{tabular}{lccccccc}
\hline Parameter divided by RWA & 1-jan-13 & 1-jan-14 & 1-jan-15 & 1-jan-16 & 1-jan-17 & 1-jan-18 & 1 -jan-19 \\
\hline & $(F=0.11)$ & $(F=0.11)$ & $(F=0.11)$ & $(F=0.09875)$ & $(F=0.0925)$ & $(F=0.08625)$ & $(F=0.08)$ \\
Core capital & $4.5 \%$ & $4.5 \%$ & $4.5 \%$ & $4.5 \%$ & $4.5 \%$ & $4.5 \%$ & $4.5 \%$ \\
Level I & $5.5 \%$ & $5.5 \%$ & $6.0 \%$ & $6.0 \%$ & $6.0 \%$ & $6.0 \%$ & $6.0 \%$ \\
PR & $11.000 \%$ & $11.000 \%$ & $11.000 \%$ & $9.875 \%$ & $9.875 \%$ & $8.625 \%$ & $8.000 \%$ \\
Capital conservation & - & - & - & $0.625 \%$ & $1.250 \%$ & $1.875 \%$ & $2.500 \%$ \\
PR + Capital conservation & $11.0 \%$ & $11.0 \%$ & $11.0 \%$ & $10.5 \%$ & $10.5 \%$ & $10.5 \%$ & $10.5 \%$ \\
Counter-Cyclical capital & - & Until 0.625\% & Until 1.25\% & Until 1.875\% & Until 2.5\% & Until 2.5\% & Until $2.5 \%$ \\
\hline
\end{tabular}




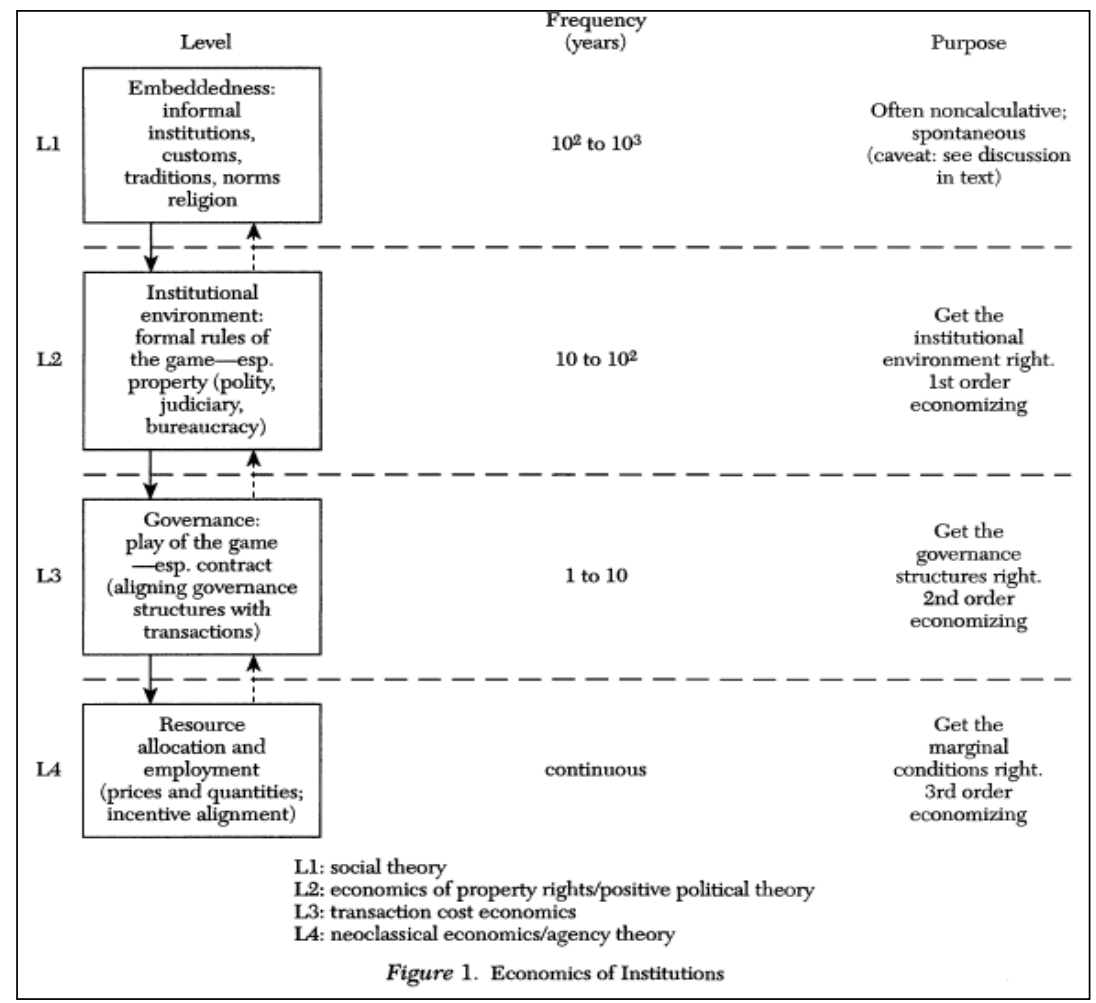

Figure C2. The new institutional economics. Source: Williamson (2000).

Appendix D: Factors for Financial Crisis-KPMG (2009)

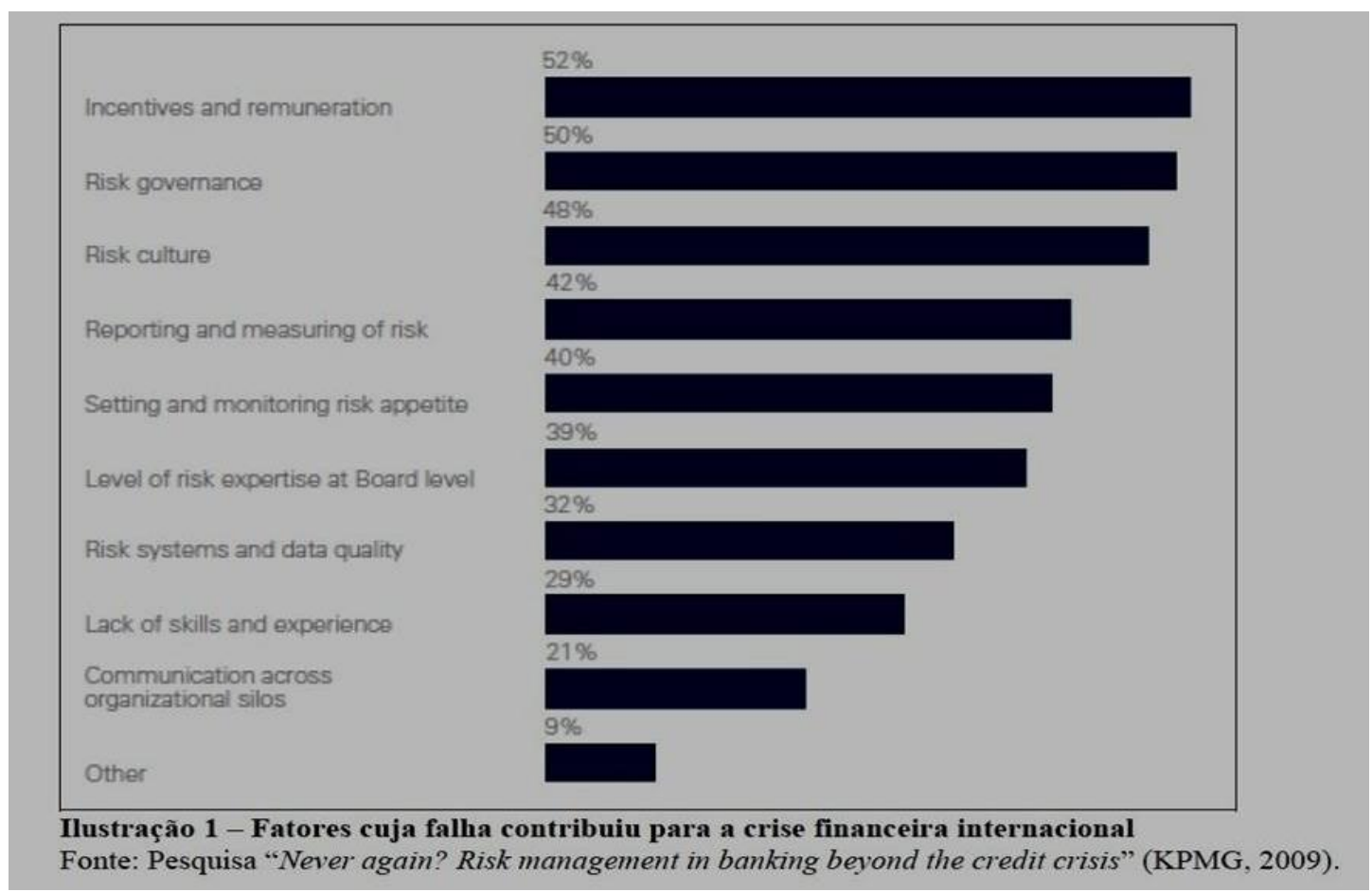

Figure D1. Factors that possibly favored the international financial crisis. 